\title{
W MUZEUM ALEGORII I LABIRYNCIE SYMBOLU. MŁODOPOLSKIE ZBŁĄDZENIA FIGUR
}

Słowa kluczowe: symbol, alegoria, literatura Młodej Polski, Stanisław Wyspiański, Stanisław Brzozowski

Keywords: symbol, allegory, Young Poland literature, Stanisław Wyspiański, Stanisław Brzozowski

„Symbol jest alegorią organiczną, wewnętrzną; korzenie jego giną gdzieś w ciemnościach; alegoria jest symbolem zewnętrznym;

korzenie ma w świetle, ale szczyt jej jest jałowym i zwiędłym."

- ten aforyzm Maurycego Maeterlincka stał się dla artystów końca XIX stulecia podstawą rozróżnienia dwóch pokrewnych figur retorycznych. Zenon Przesmycki, rozwijając tę myśl, zauważał, iż alegoria to analogia sztuczna i martwa, a niekiedy „w rzeczywistości zmysłowej istnieć nie mogąca”2, a cenny w niej jest sens ukryty, który jednak odnosi się do powierzchownej, zmysłowej strony rzeczy. Podstawę symbolu stanowi zaś odtworzenie rzeczywistości, „w której formy, postacie i zjawiska zmysłowe mają swój sens zwykły, powszedni dla ludzi zadowalających się powierzchnią, lecz dla szukających głębiej kryją w swym wnętrzu otchłanie nieskończoności” ${ }^{3}$. Dodać można, że w XIX wieku alegorii przypisywano

${ }^{1}$ Maurycy Maeterlinck, „Menus propos”, La Jeune Belgique, no. 1 (1891), in Programy i dyskusje literackie okresu Młodej Polski, ed. Maria Podraza-Kwiatkowska (Wrocław: Zakład Narodowy im. Ossolińskich, 1973), 391.

${ }^{2}$ Zenon Przesmycki, „Maurycy Maeterlinck. Stanowisko jego w literaturze belgijskiej i powszechnej", ibidem, 391-392.

${ }^{3}$ Ibidem.

${ }^{4}$ Michał Rusinek zwraca uwagę, iż wiek XIX uważany jest za okres głębokiego kryzysu retoryki, przezwyciężonego dopiero przez modernistów. Przyczyną pejoratywnego postrzegania klasycznych figur i tropów jest najpierw oświeceniowe dążenie do przejrzystości języka, a następnie romantyczne 
wartość jedynie retorycznego ozdobnika, właściwego poetyce epok dawnych, natomiast symbol miał stać się środkiem wyrazu współczesności, podwaliną nowoczesnego liryzmu 5 .

Mimo wyraźnego przeciwstawiania symbolu i alegorii w teorii i krytyce literatury dystynkcje te były często nieprecyzyjne, a niekiedy wymienione terminy traktowano jak synonimy ${ }^{6}$. Chwiejności definicji symbolu Maria Podraza-Kwiatkowska upatruje w tym, że „na przykładzie terminu posiadającego już pewne ustalone znaczenie, na przykładzie mianowicie symbolu, próbowano rozwiązywać istotne problemy estetyczne swojej epoki, że próbowano formułować nowy model poezji" 7 . Dobrym punktem wyjścia modernistycznej teorii figur wydawało się wskazanie dawnego wzoru i budowanie własnej doktryny przez przeciwstawianie mu innych jakości: prezentystyczny charakter literatury alegorycznej versus rewelatorska wartość subiektywnej poezji symbolistycznej. Włodzimierz Bolecki zauważa jednak, że symbolizm został szybko zaakceptowany w Młodej Polsce m.in. dlatego,

pragnienie wyrażenia się indywiduum w sposób autentyczny, językiem nieobciążonym przez wielowiekową tradycję. Vide Michał Rusinek, Między retoryka a retorycznościa (Kraków: Universitas, 2003),17-55. Niektórzy badacze uznają, że retoryka o korzeniach klasycznych zanikła w okresie romantyzmu, zaś współcześnie istniejąca dyscyplina tworzy nową tradycję: nie retoryki, a retoryczności. Cf. John Bender, David E. Wellbery, „Rhetoricality: On the Modernist Return of Rhetoric”, in The Ends of Rhetoric. History, Theory, Practice, ed. John Bender, David E. Wellbery (Stanford: Stanford University Press, 1990).

${ }^{5}$ Vide Ignacy Matuszewski, Stowacki i nowa sztuka (modernizm). Twórczość Stowackiego w świetle pogląów estetyki nowoczesnej. Studium krytyczno-porównawcze, ed. Samuel Sandler (Warszawa: Państwowy Instytut Wydawniczy, 1965), zwłaszcza 95-123.

${ }^{6}$ Vide Maria Podraza-Kwiatkowska, Symbolizm i symbolika w poezji Młodej Polski. Teoria i praktyka (Kraków: Wydawnictwo Literackie, 1975), 17-57.

${ }^{7}$ Ibidem, 57. Badaczka analizując teksty teoretyczne i praktykę stosowania terminu oraz zmiany w poetyce tekstów literackich, rekonstruuje definicje „symbolu” tak, jak rozumiano go w literaturze Młodej Polski: „Symbol jest to indywidualny, niekonwencjonalny, pozbawiony funkcji pedagogicznej, a także funkcji ornamentacyjnej, wieloznaczny i nieprecyzyjny, na sugerowaniu określonych wzruszeń oparty odpowiednik takich jakości, które nie będąc jakościami jasno skrystalizowanymi, nie posiadają adekwatnych określeń w systemie językowym. Symbol taki, poszerzony na szereg obrazów i analogii, niekiedy na cały utwór, na skutek kompletnegozlania się warstwy znaku i znaczenia może stać się bytem autonomicznym nie podlegającym tłumaczeniu na język d y s k u r s y w n y". Ibidem, 54. Na temat teorii symbolu w epoce cf. Henryk Chudak, ed., Symbolizm francuski i Młoda Polska. Studia i materialy (Warszawa: Uniwersytet Warszawski. Instytut Romanistyki, 1994); Wiesław Rzońca, Premodernizm Norwida - na tle symbolizmu literackiego drugiej połowy XIX wieku (Warszawa: Wydział Polonistyki Uniwersytetu Warszawskiego, 2013) czy rozprawy poświęcone Bolesławowi Leśmianowi i akcentujące wpływy symbolizmu rosyjskiego na autora Pieśni Przemądrej Wasylisy, vide Anna Sobieska, Twórczość Leśmiana w kręgu filozoficznej myśli symbolizmu rosyjskiego (Kraków: Universitas, 2005); Żaneta Nalewajk, Leśmian międzynarodowy - relacje kontekstowe. Studia komparatystyczne (Kraków: Universitas, 2015), zwłaszcza 137-151. 
że „był zarówno propozycją nowej poetyki, jak i syntezą różnych nurtów światopoglądowych obecnych już od wielu wieków w kulturze światowej - pozwalał wi ię c łączyć now oczes ność z tradycją"8 - trudno więc mówić o jego radykalnym nowatorstwie. Również operowanie terminami zakorzenionymi w tradycji retorycznej i obciążonymi bagażem znaczeń, a także ich zbyt ostra konfrontacja powodowały, iż próba zupełnego zastąpienia alegorii symbolem nie mogła się powieść. Zwłaszcza, jak sądzę, w przypadku tych twórców Młodej Polski, którzy chcąc wypowiedzieć się na temat narodowej historii, zwracali się ku przeszłości, co mogło ich skłaniać do sięgania raczej po alegorię niż symbol.

\section{„[...] termin «symbol» został faktycznie podstawiony zamiast terminu «alegoria» w akcie ontologicznej złej wiary." $"$}

Paragone alegorii i symbolu otwiera poezja końca wieku XVIII. Paul de Man zauważa sprzeczność między deklaracjami programowymi wczesnych romantyków, opowiadających się zdecydowanie za symbolem i przeciwko alegorii ${ }^{10}$, a strategiami tworzących wówczas artystów. Badacz widzi w stosowaniu symbolu próbę ocalenia podmiotowości przed działaniem czasu; ta sama motywacja skłaniała pisarzy do stronienia od alegorii. Wartością konstytutywną alegorii, stwierdza bowiem de Man, jest czas, jako że znak alegoryczny zawsze odnosi się do innego znaku, który go poprzedza: „Znaczenie tworzone przez alegoryczny znak może zatem polegać tylko na powtórzeniu (w sensie Kierkegaardowskim) tego poprzedzającego znaku, z którym ów znak nigdy nie może być współczesny, jako że do istoty poprzedzającego znaku należy czysta uprzedniość" (214). Świadome stosowanie alegorii opiera się więc na wiedzy o temporalnej nieprzystawalności języka i rzeczywistości - figura ta odwołuje się zawsze do czegoś zakotwiczonego w przeszłości, i to do znaku, nie zaś do rzeczy. Z drugiej strony jednak ustanawia związki między kolejnymi znakami, a zatem wpływa na spójność wypowiedzi.

Odmienna jest epistemologia symbolu, w którym obraz zbiega się z substancją, a więc pozostaje on „w relacji równoczesności, która tak naprawdę jest przestrzennego rodzaju, a interwencja czasu jest czymś po prostu przygodnym" (214). Zasadnicza różnica między trybami wypowiedzi rządzonymi przez obie figury polega zatem na tym, iż „symbol wysuwa możliwość tożsamości i utożsamień”, alegoria zaś „zaznacza przede wszystkim odległość względem swego początku i [...] udaremnia iluzoryczne utożsamienie «ja» i «nie-ja», które zostaje w pełni,

${ }^{8}$ Włodzimierz Bolecki, Modalności modernizmu. Studia, analizy, interpretacje (Warszawa: Instytut Badań Literackich PAN, 2012), 229.

${ }^{9}$ Paul de Man, „Retoryka czasowości”, trans. Andrzej Sosnowski, Literatura na Świecie, no. 10-11 (1999): 219. Dalsze cytaty z tego samego wydania tekstu, numery stron podaję w nawiasach.

${ }^{10}$ Podobnie jak wiek później wielu twórców Młodej Polski. 
i zarazem boleśnie, rozpoznane jako «nie-ja»” (215). Ów moment negatywności wiąże się z wyrzeczeniem, utratą i błędem, jest jednak warunkiem rozpoznania sytuacji podmiotu w zeświecczonej rzeczywistości wczesnego romantyzmu. W kolejnych dziesięcioleciach dialektyka owa przechodzi w

konflikt pomiędzy koncepcją ,ja” widzianego pod autentycznie czasowym rygorem a strategią defensywną, która stara się ukryć przed taką samowiedzą. Podkreślana na poziomie języka - tak często w XIX wieku - wyższość symbolu nad alegorią jest jedną z postaci tej nieustępliwej automistyfikacji (215).

De Man podważa więc przekonanie wielu teoretyków i twórców romantyzmu oraz modernizmu (dzielone niekiedy również przez krytykę współczesną), jakoby symbol objawiał nowe treści, dla których brakowało dotąd środków wyrazu w dawnych poetykach. Włodzimierz Bolecki stwierdza, że stosowany przez pisarzy przełomu XIX i XX wieku symbol „był de facto kry ty ką z n a ku ję zyk ow e g o (jako jednostki komunikacji o określonym znaczeniu)" "11. Mielibyśmy tu więc do czynienia $\mathrm{z}$ dewaloryzacją języka pojęciowego, a dowartościowaniem znaku symbolicznego o większej zdolności przekazywania sensów ${ }^{12}$. Jak dowodzi autor Ideologii estetycznej, jest wręcz przeciwnie: konstytutywną zasadą symbolu okazuje się ucieczka od wiedzy o nieprzystawalności rzeczywistości i języka, o tym, że próby stworzenia adekwatnej artystycznej reprezentacji rzeczywistości są skazane na klęskę. Lęk przed niemocą literatury wiąże się ze słabością podmiotu: unicestwianego przez śmierć, świadomego, że jego dzieło jest niczym wobec złożoności świata, jak on sam jest niczym wobec trwania natury. Wraz z utratą transcendentnego gwaranta powrót do wcześniejszej pełni został wykluczony; niemożliwe okazuje się przezwyciężenie śmierci czy redukcja dystansu między rzeczywistością i uniwersum znaków poetyckich. Poeta może jednak zdać sprawę ze swoich wcześniejszych złudzeń, nie powracając co prawda do dawnej kojącej iluzji, ale zyskując samowiedzę - taką możliwość daje stosowanie alegorii ${ }^{13}$.

Do podobnych wniosków dochodzi Gayatri Spivak, która - za Walterem Benjaminem $^{14}-\mathrm{w}$ alegorii widzi atut czystej subiektywności ${ }^{15}$. Badaczka zauważa,

${ }^{11}$ Włodzimierz Bolecki, Modalności modernizmu..., 231.

${ }^{12} \mathrm{Na}$ temat modernistycznego „odkrycia języka” jako źródła zarówno możliwości, jak i komunikacyjnych ograniczeń vide Ryszard Nycz, „Język modernizmu. Doświadczenie wyobcowania i jego konsekwencje", in idem, Język modernizmu. Prolegomena historycznoliterackie (Wrocław: Wydawnictwo Uniwersytetu Wrocławskiego, 2002).

${ }^{13}$ Tak dzieje się w utworze angielskiego prekursora romantyzmu Williama Wordswortha rozpoczynającym się od słów $A$ slumber did my spirit seal. Vide analiza de Mana, idem, Retoryka czasowości, 235-238.

${ }^{14}$ Vide Walter Benjamin, Źródło dramatu żałobnego $w$ Niemczech, trans. Andrzej Kopacki (Warszawa: Wydawnictwo Sic!, 2013), 207-251. Do ustaleń Benjamina odwołuje się również de Man.

${ }^{15}$ Gayatri Ch. Spivak, „Alegoria i dzieje poezji”, trans. Maria Dramińska-Joczowa, in Alegoria, ed. Janina Abramowska (Gdańsk: słowo/obraz terytoria, 2003), 104. 
że dla alegorii charakterystyczne jest powiększanie i utrzymywanie dystansu między znakiem a sensem, co tworzy „reprezentacje” języka. Spadek popularności figury po okresie renesansu autorka wiąże z podważeniem układu odniesienia alegorii $-\mathrm{z}$ osłabieniem roli przedstawień obrazowych (iconic). Dlatego też później alegoria zwraca się ku systemowi znaczeń semantycznych związanych $\mathrm{z}$ wyrazami i ich kombinacjami. W tej postaci cechuje ją predylekcja do metasemantyki, powraca też skłonność do posługiwania się przedstawieniami ikonicznymi. Oboje przywołani badacze czasowy charakter alegorii wiążą z obrazowością odnoszącą się do pejzażu naturalnego - w analizowanym przez Spivak Preludium Wordswortha to kontemplacje morza, nieba etc. wyznaczają momenty achronii, zmieniające przeżywanie linearnego czasu przez podmiot. Związek twórczej jednostki i natury jest jednak dopiero początkiem poznawczej drogi wczesnych romantyków. Wiedzie ona do odrzucenia złudnej obietnicy trwania dzięki sile świata przyrodniczego i prowadzi do rozpoznania prawdy - zapowiedzi śmierci. Odwołania do przyrody stanowią tu z jednej strony pewną pozostałość po osobowej transcendencji, z drugiej strony wiążą się z dążeniem do obrazowości, o której pisze Spivak.

Problem czasowości alegorii i przestrzenności symbolu, rozważany przez Benjamina i jego kontynuatorów, jest bardzo złożony. O ile można zgodzić się co do tego, że sama struktura alegorii wiąże się z czasowością (jako że jej znaczenie ustanawia tradycja, i jej uaktualnienie zawsze wymaga sięgnięcia $\mathrm{w}$ przeszłość), zaś symbol, oparty na utożsamieniu przedmiotu i znaczenia, wyklucza czasowy rozziew, o tyle trudno zbudować tu konsekwentne przeciwstawienie czasowości i przestrzenności. Po części zapewne ze względu na wielką popularność alegorii o charakterze ikonicznym, po części za sprawą odwołań do przyrody - oba aspekty ewokują bowiem związki z przestrzenią.

Warto odnieść się tu do wspomnianej opozycji, umożliwiającej Lessingowi rozróżnienie sztuk czasowych (literatury i muzyki) oraz przestrzennych (malarstwa, rzeźby i architektury) ${ }^{16}$. Niemiecki badacz zwraca uwagę na różne rodzaje znaków, w których te dziedziny się wypowiadają, wskazując na zależność ich typu i sposobu odbioru tekstu przez adresata komunikatu: czasowość wiąże się z percepcją elementów uszeregowanych linearnie, przestrzenność - z momentalnym, pozbawionym komponentu czasowego postrzeganiem. Rozróżnienie Lessinga w historii refleksji intersemiotycznej stało się podstawą nurtu bazującego na przekonaniu o autonomii sztuk, w przeciwstawieniu do przeświadczenia o ich korespondencji ${ }^{17}$,

${ }^{16}$ Vide Gotthold Ephraim Lessing, Laokoon czyli o granicach malarstwa i poezji. Część pierw$s z a$, ed. Jolanta Maurin Białostocka, trans. Henryk Zymon-Dębicki (Wrocław: Zakład Narodowy im. Ossolińskich, 1962).

${ }^{17}$ Vide Marta Skwara et Seweryna Wysłouch, ed., Ut pictura poesis (Gdańsk: słowo/obraz terytoria, 2006); w szczególności tekst Seweryny Wysłouch, „«Ut pictura poesis» - stara formuła i nowe problemy". 
jednak późniejsi badacze podważali ów podział. Wskazywali między innymi, że percepcja znaków ikonicznych, choć nie mają one z góry narzuconego linearnego porządku, również stanowi proces rozciągający się w czasie. Z drugiej strony, utwór literacki istnieje także w przestrzeni, ma więc po trosze charakter ikoniczny, obrazowy ${ }^{18}$. Zwrócenie uwagi na niemożność oddzielenia od siebie przestrzennego i czasowego aspektu odbioru określonego rodzaju znaków czy figur ma znaczenie w kontekście badań o charakterze komparatystycznym ${ }^{19}$, uświadamia bowiem, że związane z poszczególnymi dziedzinami dystynkcje mają charakter raczej ilościowy niż jakościowy.

Fakt, że w figurach tak, zdawałoby się, opozycyjnych, jak alegoria i symbol, nie da się wskazać dominanty czasowej lub przestrzennej, pozwala łatwiej zrozumieć, czemu konstrukcje te były często mylone lub stosowane zamiennie. Zwłaszcza iż, jak wskazywał Bolecki, symbolizm pozwalał łączyć nowoczesność $\mathrm{z}$ tradycją - wyrażać w zmodernizowanym języku poetyckim treści znakomicie w kulturze zakorzenione. Również to, że signifiants znaku symbolicznego stanowiły niejednokrotnie obrazy czy pojęcia stosowane wcześniej w przekazach alegorycznych, sprzyjało retorycznym zbłądzeniom.

\section{„O symboliczne kłamstwo, świeć nad całym polem!”20}

W literaturze Młodej Polski związek przestrzeni (zwłaszcza ojczystego pejzażu) oraz refleksji dotyczącej czasu jest nie mniej ważki niż ten, który w odniesieniu do romantyków opisuje de Man; przyczyną jest specyfika dziejowa naszej kultury. Zdaniem Stanisława Brzozowskiego w epoce dominował bowiem szczególny stosunek do historii, skutkujący „,zaprzeczaniem rzeczywistości”21. Za jego przyczynę uznać można zwrócenie ku przeszłości, które traktowano jako remedium na ówczesną sytuację polityczną. Kazimierz Wyka w pracy Modernizm polski wskazywał, że najważniejszym doświadczeniem artystów tego okresu było

${ }^{18}$ E.g. w analizowanym przez de Mana utworze Wordswortha dystans czasowy między pierwszą a drugą strofą wyznaczany jest przez ciągłość znaków językowych, co ma odbicie w ich dyspozycji na przestrzeni kartki.

${ }^{19} \mathrm{Na}$ temat wizualnego aspektu figur retorycznych vide Michał Rusinek, Retoryka obrazu. Przyczynek do percepcyjnej teorii figur (Gdańsk: słowo/obraz terytoria, 2012) oraz idem, „Wizualizowalność jako kategoria porządkująca figury retoryczne", in Intersemiotyczność. Literatura wobec innych sztuk (i odwrotnie), ed. Stanisław Balbus, Andrzej Hejmej, Jakub Niedźwiedź (Kraków: Universitas, 2004). O ikoniczności literatury vide Seweryna Wysłouch, „Od słowa do ornamentu. Semiotyczne problemy poezji konkretnej", in eadem, Literatura $i$ semiotyka (Warszawa: Wydawnictwo Naukowe PWN, 2001).

${ }^{20}$ Stanisław Wyspiański, Wyzwolenie, ed. Aniela Łempicka (Wrocław: Zakład Narodowy im. Ossolińskich, 1970), 201. Dalsze cytaty z tego samego wydania, numery stron podaję w nawiasach.

${ }^{21}$ Stanisław Brzozowski, „Studia o Wyspiańskim” in idem, Dzieła wszystkie, vol. 6, ed. Artur Górski, Stefan Kołaczkowski, Jadwiga i Bogdan Suchodolscy (Warszawa: Instytut Literacki, 1936), 321. 
zwątpienie, rozczarowanie, ruina wszelkich ideałów i zasad: „przeżyciem pokoleniowym modernistów stał się nie tyle fakt historyczny, ile wyostrzona własna świadomość ideowa, postulaty i przeciwieństwa owej świadomości. Czy też dokładniej: owa świa domość stała się faktem hist ory czny m wyróżniającym młodych" "22. Choć ustalenia badacza wielokrotnie komentowano i podważano ${ }^{23}$, niechęć twórców do zajmowania się rzeczywistością polityczną hic et nunc wydaje się istotną pokoleniową dystynkcją. Odwrócenie się od teraźniejszości wiązało się często ze skierowaniem uwagi ku dawnym chwalebnym czynom, będącym prefiguracją tego, co ma nastąpić.

Wyobrażenia o przyszłości stanowiły tu rodzaj zwierciadlanego odbicia tego, co minęło, powracającej wizji dziejów, skumulowanej rzeczywistości historycznej, jedynej dla ówczesnych ludzi rzeczywistości pewnej, namacalnej niemal, prawdziwszej niejako od zawieszonego w niedookreśleniach, mglistego, zagrożonego teraźniejszego dnia ${ }^{24}$.

Powyższa konstatacja Wiesława Juszczaka dotyczy nie tylko malarstwa, ale całej kultury artystycznej tego okresu. Znamienna wydaje się sprzeczność między deklaratywnym, wyrażającym się w lekceważeniu rzeczywistości politycznej, całkowitym odrzuceniem perspektywy dziejowej przez wielu twórców, a ciągłym zwróceniem ku przeszłości. Częściowo jest to niewątpliwie kontynuacja tendencji historycystycznych, bardzo silnych w wieku XIX. Także charakterystyczne cechy romantyzmu: inspiracje ludowością, orientalizm czy fascynacje mediewistyczne kierowały spojrzenia artystów ku temu, co dawne.

Poetycka realizacja postawy „,zaprzeczania rzeczywistości” skłaniała jednocześnie do sięgania po symbol, ustanawiający równoczesność znaku i znaczenia, nie zakładający jednak właściwego alegorii trwania. Stanowi to, jak pisał de Man, wyraz strategii defensywnej, zdradza lęk podmiotu przed czasowością, przed niesionymi przez nią zagrożeniami (w wielu młodopolskich utworach literackich czas kształtowano jako nieokreślony czy mityczny). Interesujący przy tym jest zwrot ku przestrzeni - przede wszystkim pejzażu ojczystego - która ustanawiała związek między indywidualnym podmiotem i symboliczną historią o ponadjednostkowym znaczeniu ${ }^{25}$. Rodzimy pejzaż, a nawet każdy jego element (krajobraz,

${ }^{22}$ Kazimierz Wyka, Modernizm polski (Kraków: Wydawnictwo Literackie, 1968), 62.

${ }^{23}$ Cf. Beata Szymańska, Mistycy i pesymiści. Przeżycia i uczucia jako wartości w filozofii polskiego modernizmu (Wrocław: Zakład Narodowy im. Ossolińskich, 1991); Krzysztof Fiołek, Przetrwanie i przetwarzanie. Programy kultury narodowej w epoce Młodej Polski (Kraków: Universitas, 2010).

${ }^{24}$ Wiesław Juszczak, „Modernizm”, in idem, Malarstwo polskiego modernizmu (Gdańsk: słowo/ obraz terytoria, 2004), 9.

${ }^{25} \mathrm{O}$ stosunku do natury w sztukach plastycznych Młodej Polski vide: Ewa Micke-Broniarek, „Wiosna”, Łukasz Kossowski, „O przestrzeni w malarstwie polskiego modernizmu”, in Koniec wieku. Sztuka polskiego modernizmu 1890-1914, katalog wystawy przygotowany pod kierunkiem Elżbiety Charazińskiej i Łukasza Kossowskiego (Warszawa: Muzeum Narodowe, 1996); Irena Kossowska, Łukasz Kossowski, Malarstwo polskie. Symbolizm i Młoda Polska (Warszawa: Wydawnictwo 
flora i fauna, zjawiska atmosferyczne etc.) artyści wartościują bardzo pozytywnie, jako synekdochicznie odsyłający do umistycznionej ojczyzny. W twórczości Młodej Polski zjawisko niezwykłe w zestawieniu z innymi „młodymi” literaturami europejskimi stanowi relatywnie częste dodatnie wartościowanie natury ${ }^{26}$, której modernizm, głoszący pochwałę sztuczności, był niechętny ${ }^{27}$. Wynika to niewątpliwie z utożsamiania przyrody z transcendencją - pejzaż staje się uprzestrzennioną narodową historią, której trwanie natury przydaje życia (zawieszonego jednak w achronii). Pewnego rodzaju wyparcie zachodzi też w myśleniu o otaczającej przestrzeni - ceni się ją tak wysoko właśnie dlatego, że to miejsce swoje, własne, rodzime (samowite, chciałoby się powiedzieć za Freudem). Można ją tak postrzegać jednak tylko o tyle, o ile wyruguje się świadomość realności historycznej, będącej wszak podstawą tej identyfikacji.

Warto przywołać jeszcze jeden aspekt dialektyki symbolu i alegorii, a mianowicie kwestię stosunku do materialnej warstwy rzeczywistości. Alegorię poetycką łączy pokrewieństwo z malarską, a zatem jest ona bliska zmysłowemu poziomowi zjawisk (na co zwracał uwagę np. Przesmycki w przywoływanym wyżej tekście). $\mathrm{Z}$ drugiej strony symbol często postrzegany bywał jako istotowo, substancjalnie tożsamy z wyrażaną przez niego rzeczą. Na wizualny charakter metaforyki młodopolskiej zwraca uwagę Marian Stala:

opozycja wizualność (naoczność) - awizualność (czy szerzej: sensualność, bezpośredniość przeciwstawiona czysto pojęciowej deszyfracji sensu) jest w intencjach ówczesnych twórców wyraźnie nacechowana, a wyobrażenie sensualnego i zarazem nasyconego znaczeniem obrazu, który potencjalnie tkwi w metaforze, obowiązkiem czytelnika ${ }^{28}$.

Metafora ma być zarazem niejasna i możliwa do wzrokowej konkretyzacji, potęgują to jeszcze zabiegi jej rozbijania czy sekwencjonowania, na skutek czego jej tożsamość zostaje zaburzona. Powtarzanie tych samych figur, „wskazujących

\footnotetext{
„Arkady”, 2010), 327-341. Na temat obrazu natury w literaturze okresu vide: Wacław Szelążek, Krajobraz w poezji polskiej (Warszawa: M. Arct,1919); Maria Podraza-Kwiatkowska, Symbolizm i symbolika w poezji Młodej Polski...; Jan A. Choroszy, O przestrzeni w liryce Młodej Polski. Opis typów dużych przestrzeni, „Litteraria” XXII, 1985; idem, O przestrzeni w liryce Młodej Polski. Operacje, „Prace Literackie” XXVI, Wrocław 1986; Jacek Kolbuszewski, „Krajobrazy Młodej Polski”, in Stulecie Młodej Polski. Studia, ed. Maria Podraza-Kwiatkowska (Kraków: Universitas, 1995); Anna Rossa, „Pejzaż młodopolski”, in eadem, Impresjonistyczny świat wyobraźni. Poetycka i malarska kreacja pejzażu. Studium wybranych motywów (Kraków: Universitas, 2003).

${ }^{26} \mathrm{Na}$ temat zmian w zakresie tego terminu vide Aleksandra Klich, „Pomiędzy antynomią a dopełnieniem. (Z dziejów pojęć «natura» i «przyroda» w świadomości kulturowej Młodej Polski), in Stulecie Młodej Polski...

${ }^{27}$ Vide Andrzej Nowakowski, „Apoteoza sztuczności”, in Stulecie Młodej Polski... Na temat pozytywnego obrazowania natury w sztuce Młodej Polski vide Maria Podraza-Kwiatkowska, Symbolizm i symbolika w poezji Młodej Polski..., 253-254.

${ }^{28}$ Marian Stala, Metafora w liryce Mtodej Polski. Metamorfozy widzenia poetyckiego (Warszawa: Państwowe Wydawnictwo Naukowe, 1988), 241-242.
} 
części jednorodnego pola przedmiotowego" 29 powoduje, że nawet abstrakcyjne metafory stają się po trosze wizualne, co przybliża je do innych konstrukcji, np. alegorii, a także - do symbolu. Od symbolu wszak również wymagano, aby był niejasny, zakorzeniony w otchłaniach nieskończoności, ale zarazem organiczny - aby objawiał swój sens bezpośrednio i nieodparcie. Obrazowość symbolu konotuje jego związki z rzeczywistością wizualną, z której czerpie alegoria (zwłaszcza plastyczna), co utrudnia ich rozróżnienie - tak działo się również w okresie Młodej Polski. Stala cytuje Stylistykę polska wraz z nauka kompozycji pisarskiej Piotra Chmielowskiego z 1903 roku: „Metafora rozwinięta szczegółowo nazywa się alegorią. W niej widzimy góry, kwiaty, zwierzęta przemawiające i zachowujące się jak ludzie. [...] Z alegorii takich powstały symbole [...]"30. Przywoływany fragment jasno ukazuje niestabilność pól figur w epoce, labilność ich właściwości i bardzo swobodne posługiwanie się terminami przez komentatorów. Nie przeszkadzało to jednak krytykom (i samym artystom w wypowiedziach dyskursywnych) budować ostrych i wyraźnie wartościujących opozycji między alegorią a symbolem.

Jednym z podstawowych zadań metaforyki przestrzennej w epoce było ukazanie pejzażu wewnętrznego, będącego ekwiwalentem duszy i/lub umysłu indywiduum oraz zachodzących w nich procesów i przemian ${ }^{31}$. Matuszewski wskazuje na wykorzystanie pejzażu w przedstawieniu psyche:

dzięki wzrastającej ciągle potrzebie coraz pełniejszego wypowiadania swojej jaźni wewnętrznej, artysta zaczął traktować pejzaż coraz swobodniej, aż wreszcie doszedł do tego, że zaludnił go rojem fantastycznych postaci uzmysławiających i symbolizujących wrażenia, jakie widok danego kącika i momentu natury budził w duszy artysty ${ }^{32}$.

Owe personifikacje, błąkające się po zasnutych mgłą polach, łączące w somnambuliczne korowody, zestrojone z nastrojem pejzażu to „postacie rodem z ujęć alegorycznych, ale jak gdyby oderwane od sensu alegorycznego, usamodzielnione" 33 . W tego rodzaju przedstawieniach przestrzeń nie zawsze jest jednoznacznie pozytywnie wartościowana. Podraza-Kwiatkowska zwraca uwagę na ekspansywno-agresywny charakter antropomorfizacji: natura jest tu zawłaszczana, wtłaczana w obce sobie kategorie; dzieje się tak nawet wówczas, gdy twórcy

${ }^{29}$ Ibidem.

${ }^{30}$ Cyt. za: Marian Stala, Metafora w liryce Młodej Polski..., 321.

${ }^{31}$ Vide Maria Podraza-Kwiatkowska, „Pejzaż wewnętrzny”, in eadem, Symbolizm i symbolika w poezji Młodej Polski...; Marian Stala, Pejzaż człowieka. Młodopolskie myśli i wyobrażenia o duszy, duchu $i$ ciele (Kraków: Wydawnictwo Baran i Suszczyński, 1994), zwłaszcza ibidem, „Między «zamkiem duszy» a «domkiem mego ciała». Doświadczenia ciała i cielesności jako problem i temat poezji Młodej Polski”.

${ }^{32}$ Ignacy Matuszewski, Stowacki i nowa sztuka..., 136.

${ }^{33}$ Maria Podraza-Kwiatkowska, Symbolizm i symbolika w poezji Młodej Polski..., 150. 
pragną pozytywnego kontaktu, zlania się $\mathrm{w}$ jedno z przyrodą ${ }^{34}$. Takie przedstawienie stanowi wyraz konfliktu między jednostką a światem zewnętrznym: jedną z jego przyczyn może być zderzenie się przekonania o powinnościach artysty ze świadomością własnej bezsilności oraz pragnieniem oderwania się od dawnego paradygmatu twórczego. Przyroda, utożsamiana z ojczyzną, postrzegana bywa jako zagrażająca wolności podmiotu, stąd jej negatywny obraz. Bolecki zauważa:

Zamiast przedstawiania świata zewnętrznego symboliści wprowadzili do poezji obraz świata wewnętrznego, który nazywano „pejzażem duszy” albo „pejzażem wewnętrznym”. Był to jeden ze sposobów odrzucenia problematyki społecznej i uczynienia głównym tematem wypowiedzi „ego" pisarza ${ }^{35}$.

Koncentracja na przeżyciach wewnętrznych (wyrażana często przy pomocy metaforyki przestrzennej) jest więc jedną z odmian „zaprzeczania rzeczywistości”.

Psychika twórcy i jego dzieło są po wielokroć ukazywane jako „wędrówka przez podziemia, labirynty, otwarte przestrzenie" ${ }^{36}$ czy w formie symbolu architektonicznego: jako zamki, kaplice, ruiny, nędzne budy, domy wariatów. Penetracja wnętrza, błądzenie po korytarzach posępnych budowli odpowiada eksplorowaniu rejonów nieświadomości.

Symbolika schodzenia (wchodzenia) w głąb, symbolika miast, labiryntów, grot, jaskiń, podziemnej wody itp., interpretowana jest z pozycji mistycznych jako proces puryfikacji, pozornej śmierci i zmartwychwstania oraz inicjacji, stopniowego odchodzenia od profanum do sacrum, aż do całkowitej reintegracji z absolutem ${ }^{37}$.

Często jednak jest to symbol „pustej transcendencji” w rozumieniu Hugona Friedricha ${ }^{38}$. Pejzaż wewnętrzny, prywatny (symbolizowany przez gmach) nie zostaje całkowicie odseparowany od przestrzeni przyrody. Gaston Bachelard tak właśnie tłumaczy znaczenie podziemnych jezior czy mórz, do których dotrzeć można poprzez lochy czy piwnice: stanowią one połączenie domu z naturą ${ }^{39}$. $\mathrm{W}$ sposobie przedstawienia przestrzeni zawierają się więc istotne refleksje dotyczące związków podmiotu z transcendencją i ze współczesną mu rzeczywistością. W literaturze Młodej Polski czasowy wymiar egzystencji zostaje intencjonalnie wyłączony z poetyckiego obrazowania poprzez zwrócenie się ku symbolowi, jednak powraca z powodu związków z przestrzenią, zbliżając symbol do alegorii.

\footnotetext{
${ }^{34}$ Ibidem, 137.

${ }^{35}$ Włodzimierz Bolecki, Modalności modernizmu..., 231.

${ }^{36}$ Ibidem.

${ }^{37}$ Maria Podraza-Kwiatkowska, Symbolizm i symbolika w poezji Młodej Polski..., 235.

${ }^{38}$ Vide Hugo Friedrich, Struktura nowoczesnej liryki. Od połowy XIX do połowy XX wieku, trans. Elżbieta Feliksiak (Warszawa: Państwowy Instytut Wydawniczy, 1978).

${ }^{39}$ Vide Maria Podraza-Kwiatkowska, Symbolizm i symbolika w poezji Młodej Polski..., 235.
} 
Morton W. Bloomfield, utożsamiający alegorię z procesem interpretacji, utrzymującym zrozumiałość tekstu w czasie, zwraca uwagę: „Alegoria w tym sensie pokonuje czas, nieustannie odnawia słowo pisane. Epoka, która nie potrzebuje lub sądzi, że nie potrzebuje przeszłości, nie potrzebuje także tego rodzaju alegorii. Alegoria kładzie nacisk na znaczenie nieprzerwane i ważkie" ${ }^{40}$. Teksty twórców Młodej Polski często dokumentują niejednoznaczność ówczesnego stosunku do historii, wyrażającą się między innymi w świadomym wyrzekaniu się czasowej alegorii i (deklaratywnym) wyborze achronicznego symbolu. Autorzy, zwracając się ku przeszłości, bezwiednie jednak powracali do alegorii: nie mogli wyzwolić się od tej figury, ale nie potrafili też zaakceptować jej ostatecznego znaczenia: konfrontacji ze śmiercią i daremności poetyckiego gestu przywoływania rzeczywistości. W ciągłej oscylacji twórców i odbiorców sztuki między symbolem i alegorią można się dopatrywać „aktu ontologicznie złej wiary”, o którym wspomina de Man.

\section{„W niewiadomości człowiek żyje, w niewiadomości błogosławion." 41}

Na uparte odwracanie oczu, doszukiwanie się zawiłych znaczeń symbolicznych tam, gdzie królują łatwe do odczytania alegorie, zwracał uwagę Stanisław Brzozowski w Studiach o Wyspiańskim ${ }^{42}$. Współczesnej polskiej kulturze Brzozowski przypisywał „literacko-estetyczny stosunek do życia” ${ }^{43}$; przyczyn tego stanu rzeczy upatrywał w zbytnim zanurzeniu współczesnych twórców w dziedzictwie polskiego romantyzmu, przede wszystkim nurtu mesjańskiego, i nasileniu tendencji martyrologicznych ${ }^{44}$. Za symptomatyczny dla postawy „zaprzeczenia

${ }^{40}$ Morton W. Bloomfield, Alegoria jako interpretacja, trans. Zdzisław Łapiński, in Alegoria, 53.

${ }^{41}$ Stanisław Wyspiański, Wyzwolenie, 167.

${ }^{42}$ Stanisław Brzozowski, Studia o Wyspiańskim. Twórczość autora Wesela komentował też w dziele Legenda Młodej Polski. Studia o strukturze duszy kulturalnej (Kraków - Wrocław: Wydawnictwo Literackie, 1983), 527-589. Na temat relacji obu twórców vide e.g. Magdalena Popiel, „Brzozowski - Wyspiański. Dwie formuły "pathosu wyjątkowości»", in Konstelacje Stanisława Brzozowskiego, ed. Urszula Kowalczuk, Andrzej Mencwel, Ewa Paczoska, Paweł Rodak (Warszawa: Wydawnictwa Uniwersytetu Warszawskiego \& Narodowe Centrum Kultury, 2012).

${ }^{43}$ Józef Spytkowski, Stanisław Brzozowski: estetyk-krytyk (Kraków: W.L. Anczyc i Spółka, 1939), 91.

${ }^{44}$ Również ocena dokonań romantyków podlegała w pisarstwie Brzozowskiego zmianom, cf.: Józef Spytkowski, Stanisław Brzozowski: estetyk-krytyk; Andrzej Walicki, „Stanisław Brzozowski i filozofia polskiego romantyzmu”, Studia Filozoficzne, no. 4 (1969); „«Niech Polacy się w końcu obudzą» - Stanisław Brzozowski a koszmary polskiego romantyzmu. Rozmowa z Agatą Bielik-Robson”, Ruch Filozoficzny, no. 2 (2010); Tomasz Tadeusz Brzozowski, „Stanisław Brzozowski wobec myśli filozoficznej romantyzmu polskiego", Acta Universitatis Lodziensis. Folia Philosophioca, no. 23 (2010). Także stosunkowi do polskiego patriotyzmu spod znaku Sarmatii Brzozowski dawał wyraz zarówno w tekstach krytycznych, jak i w powieściach. Problem ten analizuje Krzysztof Fiołek, vide idem, „W płomieniach polskości. Stanisław Brzozowski wobec «sprawy narodowej»”, in Stanisław Brzozowski. Powroty, ed. Dariusz Trześniowski (Radom: Uniwersytet Technologiczno-Humanistyczny. Wydawnictwo, 2013). 
rzeczywistości” Brzozowski uważa bałwochwalczy stosunek do twórczości dramatycznej autora Wesela, połączony z jej powszechnym niezrozumieniem: mimo wyartykułowanej w kolejnych sztukach wyraźnej krytyki stanu społeczeństwa polskiego zarówno z czasów współczesnych obu autorom, jak i z epok poprzednich, Wyspiański uważany jest za piewcę przeszłości, odczytującego w dawnej historii znaki prefigurujące przyszłe losy narodu. Tymczasem, zdaniem autora Legendy Młodej Polski, od najwcześniejszych sztuk pisarz w różnych szatach przedstawia tę samą treść; „głos poety mówi: przeszłości już nie ma. Jesteście tylko wy. Macie tylko siebie. Z grobu nie wróci nikt. Jest tylko życie" ${ }^{45}$.

Kulminację tej tendencji - krytyki przywiązania do przeszłości - stanowi w opinii Brzozowskiego opublikowany i wystawiony w 1903 roku dramat Wyzwolenie, który Alicja Okońska określiła jako „walkę z poezją grobów” ${ }^{46}$. Rzeczywiście sztuka ta uważana jest przez współczesnych badaczy za nawiązującą niezwykle zażartą polemikę z tradycją romantyczną i z dominującą w XIX wieku wizją historyzmu ${ }^{47}$. Historyczna przestrzeń odgrywa w niej znaczącą rolę ${ }^{48}$. Jej charakterystyka jest dość szczególna: na samym wstępie didaskalia wskazują, iż „Rzecz napisana w roku 1902 dzieje się na scenie teatru krakowskiego”, tam niewątpliwie rozgrywa się akt pierwszy (pojawiają się wzmianki o ustawianiu dekoracji, scenie i jej oświetleniu). Scenografia, tworzona według projektów Konrada przewodzącego zgromadzonym na scenie pracownikom teatru, przedstawia ,jakby salę sejmową" (19), ale zawiera też pomniki znajdujące się w kaplicy na Wawelu. Teatr określany jest przezeń jako „dom piękności” (19), „świątynia sztuki” (18) - nie jest jedynie sferą rozrywki. „Chcemy go stroić, chcemy go malować, | Chcemy w teatrze tym Polskę budować!” (19) - tak kończy się opis tworzenia dekoracji. Pojawiają się tu, prócz Konrada, Reżyser oraz aktorzy, występujący w podwójnych rolach; pracowników teatru debatujących nad właściwym kształtem sztuki oraz kreowanych osób: Muzy (okaże się kochanką Reżysera), Karmazyna, Hołysza, Prezesa, Przodownika, Kaznodziei, Prymasa, Harfiarki, Samotnika etc., personifikujących postawy Polaków przełomu XIX

${ }^{45}$ Stanisław Brzozowski, Studia o Wyspiańskim, 346.

${ }^{46}$ Alicja Okońska, Stanistaw Wyspiański (Warszawa: Wiedza Powszechna, 1971), 289.

${ }^{47}$ Vide Aniela Łempicka, „Wstęp”, in Stanisław Wyspiański, Wyzwolenie, zwłaszcza XCIV-CXVII; Maria Prussak, „Po ogniu szum wiatru cichego”. Wyspiański i mesjanizm (Warszawa: Instytut Badań Literackich PAN, 1993); eadem, Wyspiański w labiryncie teatru (Warszawa: Instytut Badań Literackich PAN, 2005), 5-14, 85 i nast.; Dariusz Kosiński, Polski teatr przemiany (Wrocław: Instytut im. Jerzego Grotowskiego, 2007), zwłaszcza 187-225. Na temat recepcji Wyzwolenia w epoce vide Michał Głowiński, „Konstelacja Wyzwolenia”, in idem, Ekspresja i empatia. Studia o mtodopolskiej krytyce literackiej (Kraków: Wydawnictwo Literackie, 1997), 306-358.

${ }^{48} \mathrm{Na}$ temat znaczenia Wawelu w twórczości Wyspiańskiego oraz w kulturze polskiej przełomu XIX i XX wieku vide Ewa Miodońska-Brookes, „Wstęp”, in Stanisław Wyspiański, Akropolis, ed. Ewa Miodońska-Brookes (Wrocław: Zakład Narodowy im. Ossolińskich, 1985), VIII-XVIII, XXXII-XLVI. 
i XX wieku ${ }^{49}$. Akt II opatrzony jest tylko adnotacją „Inna dekoracja”, nie wiemy więc, czy chodzi o zmianę scenografii „na scenie teatru krakowskiego”, czy o przeniesienie akcji sztuki w odmienną przestrzeń. Nie ma tu wzmianek o jej materialnych składnikach, a występujące postaci wydają się nierzeczywiste. Ta scena to typowa alegoria - ukazuje dialog Konrada z Maskami, personifikującymi poglądy, z którymi ściera się bohater ${ }^{50}$; przestrzeń okazuje się więc „teatrem myśli”"51. Ostatnia odsłona rozgrywa się w Kaplicy Zygmuntowskiej, będącej zarazem, jak możemy przypuszczać, sceną z aktu I (didaskalia wskazują dosłownie: W KATEDRZE NA WAWELU $(168)^{52}$. Powraca tu połączenie iluzji widowiska z realiami teatru - wyzwolone spod władzy Geniusza postaci przekształcają się ponownie w grających role aktorów i rozchodzą się do domów.

Utwór stanowi bardzo ostrą krytykę i ówczesnego stanu społeczeństwa, i „duchowej dyktatury literatury romantycznej”" ${ }^{3}$, jak pisze Jan Tomkowski. Ta negatywna ocena wydaje się rzutować też na miejsce akcji. Podwójna rola sceny krakowskiego teatru w odsłonie pierwszej nadaje ukazanemu w akcie III Wawelowi charakter sztuczny, nieautentyczny. Z kolei przestrzeń w części drugiej jest raczej rodzajem pejzażu wewnętrznego - ale nie o cechach rewelatorskiego symbolu, a alegorii, która nowych znaczeń wnieść nie może. Wyspiański ukazuje, jak niewłaściwy stosunek do przeszłości może owocować błędną diagnozą współczesności i uniemożliwić budowanie nowej, niepodległej ojczyzny. Upiory zemsty wydostają się z sakralizowanej, nadwartościowanej przeszłości, aby szerzyć zniszczenie przez kolejne dziesięciolecia, a może i wieki, póki Polacy nie zrozumieją, że to nie krypty królów są centrum kraju i źródłem jego odnowy

${ }^{49}$ Identyfikacji pierwowzorów tych postaci dokonuje Aniela Łempicka, vide eadem, „Wstęp”, zwłaszcza XXXV-XCIV.

${ }^{50} \mathrm{~W}$ wierszowanych objaśnieniach na początku aktu czytamy, że w sporze z Maskami Konrad: „W tej walce z myślą walczy własną, | by ujrzeć ją dla siebie jasną”. I dalej: „Człowiek, z myślenia ciągłą walką, | tragiczną staje się tu lalką, | zamaskowany maską stałą, | jakby bez duszy było ciało" $(59-60)$.

${ }^{51}$ Na temat stosowanych przez Wyspiańskiego strategii rozbijania iluzji scenicznej vide Krystyna Ruta-Rutkowska, Polska tradycja metadramatu. Wybrane zagadnienia (Warszawa: Wydział Polonistyki Uniwersytetu Warszawskiego, 2012), zwłaszcza 136-162. Agata Balsamo, „Patrz jak ci każę, czyli o ramie dzieła literackiego w Wyzwoleniu Stanisława Wyspiańskiego", Elewator, no. 3 (2014). $\mathrm{Na}$ temat rytualizacji przestrzeni Wawelu (w dramacie Akropolis) pisze Iwona E. Rusek; eadem, „Obudź się - zapomnij - żyj. Akropolis Stanisława Wyspiańskiego", in Młodopolski witalizm. Modernistyczne witalizmy, ed. Anna Czabanowska-Wróbel et Urszula M. Pilch (Kraków: Wydawnictwo Uniwersytetu Jagiellońskiego, 2016).

${ }^{52}$ Narzuca się tu analogia do powstałego dwa lata wcześniej Wesela: w akcie I następuje ekspozycja realnych postaci w rzeczywistej, konkretnie i szczegółowo określonej przestrzeni, w odsłonie II bohaterowie konfrontują się z personami o charakterze fantastycznym, co odbiera realność również otoczeniu, wreszcie w akcie III oba światy przenikają się, zaś postępki osób dramatu mają wpływ na dalsze losy Polski.

${ }^{53}$ Jan Tomkowski, „Posłowie”, in Stanisław Wyspiański, Cztery dramaty, ed. Jan Tomkowski (Warszawa: „Świat Książki”, 2002), 679. 
- tej dokonać może tylko praca w realnej przestrzeni. Podkreśla to charakter nadzorowanego przez Wyspiańskiego wystawienia spektaklu:

Wyzwolenie - być może najbardziej „teatralny” dramat Wyspiańskiego, w przeciwieństwie do „bajecznie kolorowego” Wesela rozgrywany w mroku pustej sceny [...]. Odrzucając dekoracje, korzystając nader oszczędnie z symbolicznych rekwizytów, Wyspiański nie poprzestaje na narodowych obrachunkach. Zgłębia również istotę teatralnej iluzji, próbuje przekroczyć granice dzielące widownię od sceny oraz teatr od świata rzeczywistego ${ }^{54}$.

Można odnieść wrażenie, że dramaturg, czyniąc Wawel sceną swojej sztuki, chciał zdemaskować niszczącą siłę przywiązania do zabytków przeszłości, wskazać, iż przeszłość jest nierzeczywista - jak teatr. „Wierzy, że trzeba opuścić świat sztuki, wydobyć się z królestwa fikcji, obudzić się z pięknego snu, by powrócić w objęcia twardej rzeczywistości” ${ }^{55}$.

Takiej diagnozy współcześni Wyspiańskiemu odbiorcy, zafiksowani na mitycznej wizji historii, nie byli w stanie przyjąć. O niezrozumieniu intencji sztuki mówił sam jej autor: „Ani jeden mnie nie zrozumiał, ani jeden $\mathrm{z}$ recenzentów nie pojął, o co mi chodziło, nie wszedł w moje intencje [...]"56. Józef Kotarbiński, dyrektor teatru wystawiającego spektakl, przytaczał takie opinie dramatopisarza: „Przede wszystkim poeta zastrzegł się wyraźnie, że w jego dziełach nie trzeba się domyślać tego, co nie było drukowane. [...] Kto widział więc Wyzwolenie na deskach scenicznych, nie powinien czekać na nic więcej, ale brać to, co jest, bo nic nowego się nie stanie" ${ }^{\text {"57 }}$. Widzom to jednak nie wystarczało - pod każdym elementem dramatu domyślano się tajemniczych, istotnych sensów zamiast uznać, że groby i trupy konotują zagrożenie i śmierć. Współczesnym Wyspiańskiemu przyjęcie jego alegorii utrudniać mogło to, że - jak wynika z uwag Brzozowskiego - sam twórca Wyzwolenia przeżywa, podobnie jak inni autorzy (i odbiorcy) Młodej Polski, niemożność utożsamienia się z postawą afirmującą życie ${ }^{58}$, a zatem niemożność bycia tu i teraz.

${ }^{54}$ Ibidem, 675 .

${ }^{55}$ Ibidem, 679. Wydobycie się z królestwa fikcji możliwe jest dzięki destrukcji jego nieautentycznej przestrzeni. W finale Akropolis, stanowiącego zwieńczenie trylogii zapoczątkowanej przez Wesele i Wyzwolenie, Kaplica Zygmuntowska zostaje zniszczona; ofiara ta umożliwia nadejście Zbawiciela.

${ }^{56}$ Zenon Parvi, „U Wyspiańskiego”, in Wyspiański w oczach wspótczesnych, vol. 2, ed. Leon Płoszewski (Kraków: Wydawnictwo Literackie, 1971), 62. Przytaczana wypowiedź pochodzi z 1903 roku.

${ }^{57}$ Józef Kotarbiński, „Uwagi o Wyzwoleniu. (Na tle rozmowy z autorem)”, in Wyspiański w oczach wspótczesnych, 63-64. Różnica między tekstem drukowanym (zawierającym obszerne, wierszowane didaskalia), a tym, co można usłyszeć z widowni, jest jednak znaczna. Cf. Aniela Lempicka, „Wstęp”; Krystyna Ruta-Rutkowska, Polska tradycja metadramatu...

${ }^{58} \mathrm{Na}$ temat dialektyki życia i śmierci w twórczości Wyspiańskiego vide Mateusz Antoniuk, „Co żywe, ma ożyć... O «manuskryptowym witalizmie» Stanisława Wyspiańskiego” i Wojciech Gutowski, „Wątpliwa hipoteza witalizmu w polskiej literaturze nowoczesnej”, in Młodopolski witalizm. Modernistyczne witalizmy... 
Przekonywa sam siebie rozumowanymi argumentami, że ono jest, ale nie pozostaje z nim w żadnym bezpośrednim stosunku. Nie czuje, że bierze w nim udział, nie wie czy bierze. [...] Jeżeli jest życie, to jest ono dla niego nieobecne. Jedyną formą życia znaną mu i bliską jest przeszłośćs ${ }^{59}$.

Nieporozumienie wokół Wyzwolenia sugestywnie potwierdza, że literatura Młodej Polski oscyluje między symbolem, pozwalającym utrzymać projektowaną wizję historii narodowej, a alegorią, dzięki swej narracyjnej strukturze znacznie lepiej się do tego nadającą: ta ostatnia figura musiała jednak zostać odrzucona jako artykułująca nieuchronność śmierci i przemijania. Twórcy byli więc skazani na wybór między labiryntem ${ }^{60}$ symbolu a muzeum alegorii. Ściany labiryntu odgradzały ich od przygnębiającej rzeczywistości historycznej, ale nie pozwalały też zapomnieć o sztuczności tworzonej przez niego przestrzeni; korzystanie $\mathrm{z}$ alegorii umożliwiało kontemplację dawnej chwały, przypominało jednak o jej nieaktualności. Im bardziej wypierano perspektywę współczesnej politycznej klęski, zamieniając każdy kamień krakowskiego bruku w place Nowej Jeruzalem, tym mocniej „zaprzeczona rzeczywistość” powracała, zabarwiając trupią bladością każdy pierwiastek teraźniejszości.

Rozwiązanie przynieść mogłoby zastosowanie obrazowania alegorycznego i jednoczesne odwołanie do natury, która zapewnia trwanie podmiotu (taką strategię wybierali omawiani przez de Mana i Spivak poeci wczesnego romantyzmu). Jednak przybierające na sile utożsamienie pejzażu, geograficznie określonej przestrzeni z ojczyzną powodowało, że przyroda nie mogła być dla podmiotu przestrzenią kontemplacji ani też źródłem siły, ponieważ nieustannie przypominała o niespełnionym obowiązku walki o niepodległość. Jeśli w literaturze czy malarstwie epoki udało się przekroczyć granicę między sztuką a rzeczywistością, to raczej cały kraj zamieniał się w scenę, na której powtarzał się - wciąż ten sam - patriotyczny spektakl. Niebezpieczeństwo to rozpoznał i starał się wskazać Wyspiański, przedstawiając w swoich dramatach diagnozę trapiącej kulturę Młodej Polski gorączki romantycznej.

${ }^{59}$ Stanisław Brzozowski, Studia o Wyspiańskim, 358.

${ }^{60}$ Pojęcie to czerpię z Hamleta Wyspiańskiego; w dedykacji poeta mówi o „labiryncie zwanym teatrem" (Stanisław Wyspiański, Hamlet, ed. Maria Prussak (Wrocław: Zakład Narodowy im. Ossolińskich, 1976). Na temat tej metafory vide Dobrochna Ratajczakowa, „W labiryncie”, in Stanistaw Wyspiański. Studium artysty. Materiały z sesji naukowej na Uniwersytecie Jagiellońskim, 7-9 czerwca 1995, ed. Ewa Miodońska-Brookes (Kraków: Universitas, 1996); Dariusz Kosiński, Polski teatr przemiany, 222-237. 


\section{IN THE MUSEUM OF ALLEGORY AND LABYRINTH OF SYMBOL. MISGUIDANCE OF FIGURES IN YOUNG POLAND LITERATURE}

\section{Sum mary}

The essential problem discussed in this paper is the use of rhetorical figures, symbol, and allegory in Young Poland Literature. In the discourse of literary criticism of this period authors expressed their intentions to replace allegory, which was associated with traditional, widely-held ways of creating meanings, with symbol, which was considered modern and polysemous. Surprisingly, the artistic practice did not follow these theoretical declarations as writers still frequently used allegorical constructions. In the article, the author tries to analyse the reasons of this state of affairs using theories of Walter Benjamin, Paul de Man and Gayatri Spivak.

As an example of difficulties in the replacement of allegory by symbol in the period of Young Poland, the author proposes an interpretation of Stanisław Wyspiański's drama Liberation. In this work, the poet criticizes the dependency of Polish culture at the turn of the nineteenth and twentieth centuries on the ideas of Romanticism (this quality is also condemned by Stanisław Brzozowski, commentator and interpreter of Wyspianski's works). Contemporary readers, despite the greatest acknowledgement for the author of The Wedding, did not accept the poet's ideas. The reasons for this was readers' hunt for symbolic meanings where the author used plain allegories. 